TARNOWSKIE STUDIA TEOLOGICZNE 37 (2018) NR 1-2, S. 299-312 http://dx.doi.org/10.15633/tst.3264

ks. Andrzej Sułek ${ }^{1}$

UNIWERSYTET PAPIESKI JANA PAWŁA II W KRAKOWIE

\title{
Współpraca rodziny i szkoły w wychowaniu patriotycznym jako wyraz troski o prawidłowy rozwój postaw społecznych dziecka. Recepcja wniosków $z$ badań dla wychowania patriotycznego
}

Setna rocznica odzyskania przez Polskę niepodległości jest dobrą okazją do pogłębienia refleksji nad postawami patriotycznymi Polaków oraz wychowaniem patriotycznym młodego pokolenia. Zarysowana w niniejszym opracowaniu problematyka jest częścią programu badawczego, podjętego w celu rozpoznania, jak kształtują się postawy wobec ojczyzny i narodu oraz jakie są ich psychospołeczne źródła. Ukazanie w wyniku badań, jakie cechy psychiczne oraz jakie czynniki społeczne stanowią źródła patriotyzmu, nacjonalizmu i kosmopolityzmu może stanowić cenną pomoc w konstruowaniu programów i wskazań wychowawczych w procesie kształtowania postawy patriotycznej. W artykule tym przytoczę tylko najważniejsze wnioski z badań, dotyczące postawy patriotycznej ${ }^{2}$.

\section{Patriotyzm jako postawa społeczna}

Postawę rozumiemy jako „względnie stałe ustosunkowanie, które wyraża się w gotowości podmiotu do pozytywnych lub negatywnych reakcji

\footnotetext{
1 Ks. Andrzej Sułek - kapłan diecezji tarnowskiej, teolog, doktor nauk humanistycznych w zakresie psychologii, wykładowca w Uniwersytecie Papieskim Jana Pawła II w Krakowie Wydział Teologiczny Sekcja w Tarnowie, dyrektor Diecezjalnego Ośrodka Pomocy Psychologicznej Osobom Duchownym, Konsekrowanym i Świeckim w Tarnowie, wiceprezes Zarządu Stowarzyszenia Poradnia Specjalistyczna i Telefon Zaufania ARKA w Tarnowie.

2 Ta tematyka została szeroko omówiona w publikacji: A. Sułek, Psychospołeczne uwarunkowania patriotyzmu i nacjonalizmu, Kraków 2012.
} 
(intelektualnych, emocjonalnych i behawioralnych) wobec jej przedmiotu"3. Przedmiotem postawy jest m.in. człowiek lub grupa społeczna, stąd wyprowadza się postawy społeczne, do których zaliczyć można: odpowiedzialność za dobro wspólne, solidarność, obowiązkowość, miłość społeczną, altruizm, odwagę, prawość, współpracę, wyrozumiałość, pojednawczość, troskę o innych, towarzyskość. Do postaw społecznych należy również patriotyzm. A ponieważ postawę patriotyczną można traktować jako zespół postaw ${ }^{4}, \mathrm{w}$ swoich badaniach opisuję patriotyzm jako postawę człowieka, który ma pozytywne i zaangażowane nastawienie do własnego narodu (traktuje dobro własnego narodu jako ważniejsze niż dobro innych narodów czy całej ludzkości, ma silne poczucie tożsamości narodowej - czuje więź z narodem, odczuwa wyraźnie potrzebę przynależności do narodu, jest gotów do pracy i poświęcenia dla swojej ojczyzny, troską ogarnia dobro narodu, ma szacunek dla tradycji i historii, ponadto zna tradycję i historię oraz ma potrzebę dalszego jej poznawania) i ma również nastawienie pozytywne do innych narodów (otwarty na inne narody, umie dostrzegać dobro i wartości tkwiące $\mathrm{w}$ innych narodach, jest otwarty na współpracę z innymi narodami, dążąc do obopólnych korzyści, akceptuje inne narody) 5 .

\section{Zarys przeprowadzonych badań i uzyskanych wyników}

W celu zbadania poziomu patriotyzmu została skonstruowana Skala Postaw Wobec Ojczyzny ${ }^{6}$, natomiast w celu zbadania zmiennych psychologicznych i społecznych, które jak wynikało z literatury przedmiotu i z obserwacji życia mogłyby tłumaczyć genezę patriotyzmu, wykorzystano metody badające następujące zmienne: potrzeby jednostki',

3 W. Prężyna, Intensywność postawy religijnej a osobowość, Lublin 1973, s. 25.

4 T. Mądrzycki, Psychologiczne prawidłowości kształtowania się postaw, Warszawa 1977, s. 67 .

5 Z. Blok, Status teoretyczny kategorii: nacjonalizm, patriotyzm, kosmopolityzm i internacjonalizm, w: Człowiek i społeczeństwo, t. 11, Poznań 1994, s. 147-154.

6 Więcej o tej metodzie zob. A. Sułek, Psychospołeczne uwarunkowania patriotyzmu..., s. $85-86$.

7 Test Przymiotników (The Adjective Check List - ACL) H. G. Gougha i A. B. Heilbruna w wersji z 1980 roku wieloaspektowo bada 37 wymiarów osobowości człowieka. Według autorów test jest metodą badania obrazu siebie. Zadaniem osoby badanej jest wybranie spośród 
preferowane wartości ${ }^{8}$, orientacje indywidualizmu i kolektywizmu ${ }^{9}$, religijnośćc ${ }^{10}$, aprobatę społeczną ${ }^{11}$ (zmienne osobowościowe) oraz oddziaływanie rodziny, szkoły i wspólnot, w tym również religijnej (zmienne społeczne ${ }^{12}$ ). Związki patriotyzmu z poszczególnymi zmiennymi wyodrębniono m.in. poprzez procedurę korelacyjną ${ }^{13}, \mathrm{z}$ której główne wnioski przydatne do pracy wychowawczej zostaną przytoczone poniżej.

300 przymiotników tych, którymi opisuje siebie: jaki jestem (obraz realny) oraz jaki chciałbym być (obraz idealny). W badaniach zastosowano cały test, natomiast w niniejszym opracowaniu wykorzystano tylko wyniki ze skal potrzeb. Por. H. G. Gough, A. B. Heilbrun, The Adjective Check List Manual, Paolo Alto 1965; H. G. Gough, A. B. Heilbrun, The Adjective Check List Manual, Paolo Alto 1983.

${ }^{8}$ Kwestionariusz Preferencji Wartości (Value Survey) Rokeacha bada system wartości. Kwestionariusz składa się z dwóch części: z listy 18 wartości ostatecznych oraz listy 18 wartości instrumentalnych. Zadaniem osoby badanej jest uporządkowanie każdej z tych list według ważności tych wartości w życiu tej osoby. Por. M. Rokeach, The Nature of Human Values, New York 1973; także: J. Śliwak, Osobowość altruistyczna. Osobowościowe korelaty altruizmu, Lublin 2001; P. Brzozowski, Polska wersja Testu Wartości Rokeacha i jej teoretyczne podstawy, „Przegląd Psychologiczny" 2 (1986), s. 527.

9 Skala Indywidualizmu - Kolektywizmu Adamskiej służy do pomiaru orientacji indywidualistycznych i kolektywistycznych. Zawiera 3 skale: indywidualizmu, kolektywizmu i afiliacji. Zob. K. Adamska, Mapa rzeczywistości społecznej indywidualisty i kolektywisty - badania empiryczne, „Przegląd Psychologiczny” 3-4 (1997), s. 443-464.

${ }^{10}$ Skala Postaw Religijnych Prężyny służy do pomiaru intensywności postawy religijnej. Zob. W. Prężyna, Skala Postaw Religijnych, „Roczniki Filozoficzne” 1968 z. 4, s. 75-89; W. Prężyna, Intensywność postawy religijnej a osobowość, Lublin 1973. Wykorzystano skróconą wersję skali (21 itemów) oraz 6 niestandaryzowanych itemów tworzących Skalę Kryzysu Religijnego. Por. W. Prężyna, Skala Postaw Religijnych, s. 75-89; także: W. Prężyna, Kryzys religijny a cechy osobowości, „Roczniki Filozoficzne” 1971 z. 4, s. 25-135.

${ }^{11}$ Kwestionariusz Aprobaty Społecznej Kas Drwala i Wilczyńskiej służy do badania wpływu potrzeby aprobaty społecznej na zachowanie osób badanych. Zob. R. Ł. Drwal, J. T. Wilczyńska, Opracowanie Kwestionariusza Aprobaty Społecznej, „Przegląd Psychologiczny” 3 (1980), s. 569-583; także: J. Wilczyńska, R. Ł. Drwal, Opracowanie Kwestionariusza Aprobaty Społecznej (KAS) J. Wilczyńskiej i R.Ł. Drwala, w: R. Ł. Drwal, Adaptacja kwestionariuszy osobowości. Wybrane zagadnienia i techniki. Pod redakcja Piotra Brzozowskiego przy wspótpracy Piotra Olesia, Warszawa 1995, s. 57-66.

${ }^{12}$ Arkusz Środowiskowy własnej konstrukcji został opracowany dla analizy wpływu czynników społecznych na postawy wobec ojczyzny i narodu. Czynnikami tymi są 1. oddziaływania rodziny; 2. szkoły; 3. wspólnoty religijnej; 4. działania i doświadczenia własne jednostki; oraz 5. oddziaływania grup rówieśniczych i organizacji. Metroda składa się z 99 itemów ujętych w 10 skalach. Więcej o metodzie zob. A. Sułek, Psychospołeczne uwarunkowania patriotyzmu..., s. 92-93.

${ }^{13}$ Korelacja wskazuje związek między zmiennymi. Może ona przyjąć wartości liczbowe w przedziale <-1;1>. Im większa wartość bezwzględna, tym silniejszy związek między badany- 
Do analiz wykorzystano wyniki 314 osób (141 mężczyzn i 173 kobiet) w różnym wieku od 16 do 65 lat (średnia 32, 8 lat), z różnym wykształceniem i miejscem zamieszkania. W skali patriotyzmu badani mogli uzyskać wyniki w przedziale od 45 do 335 punktów (faktycznie wyniki mieściły się w przedziale między 88 a 309 punktów).

\section{Uwarunkowania patriotyzmu w świetle przeprowadzonych badań ${ }^{14}$}

W tym miejscu przyjrzyjmy się wynikom korelacji patriotyzmu z poszczególnymi zmiennymi obliczonym osobno dla grupy mężczyzn i grupy kobiet. Pozwoli to zobaczyć podobieństwa i różnice co do uwarunkowań patriotyzmu między grupami mężczyzn i kobiet. Poniższa tabela 1 zawiera najważniejsze korelacje istotne statystycznie, uszeregowane w grupach mężczyzn i kobiet od najmocniejszych do najsłabszych.

Tabela 1. Korelacje istotne statystycznie dla patriotyzmu w grupach mężczyzn i kobiet

\begin{tabular}{lcclcc}
\hline \multicolumn{1}{c}{ MĘżczYźNI } & & \multicolumn{3}{c}{ KOBIETY } & \\
\hline Skale & r Pear-sona & Istotność & Skale & r Pear-sona & Istotność \\
\hline $\begin{array}{l}\text { Patriot. oddział. } \\
\text { domu }\end{array}$ & 0,536 & .000 & $\begin{array}{l}\text { Intensywność } \\
\text { post. religijnej }\end{array}$ & 0,447 & .000 \\
\hline $\begin{array}{l}\text { Intensywność post. } \\
\text { religijnej }\end{array}$ & 0,522 & .000 & $\begin{array}{l}\text { Patriot. oddział. } \\
\text { Kościoła }\end{array}$ & 0,341 & .000 \\
\hline $\begin{array}{l}\text { Patriot. oddział. } \\
\text { Kościoła }\end{array}$ & 0,466 & .000 & $\begin{array}{l}\text { Patriot. oddział. } \\
\text { domu }\end{array}$ & 0,334 & .000 \\
\hline $\begin{array}{l}\text { Patriot. aktywność } \\
\text { własna }\end{array}$ & 0,448 & .000 & $\begin{array}{l}\text { Patriot. aktyw- } \\
\text { ność własna }\end{array}$ & 0,332 & .000 \\
\hline $\begin{array}{l}\text { Bezpieczeństwo } \\
\text { narodowe }\end{array}$ & 0,433 & .000 & $\begin{array}{l}\text { Patriot. oddział. } \\
\text { szkoły }\end{array}$ & 0,324 & .000 \\
\hline
\end{tabular}

mi zmiennymi. Znak (+) oznacza zależność dodatnią (im silniejsza jedna zmienna, tym silniejsza druga), natomiast znak (-) oznacza korelację ujemną (im silniejsza jedna zmienna, tym słabsza druga). Istotność różnic, np..005, wskazuje, że istnieje prawdopodobieństwo mniejsze niż 0,005 , że tak wysoka korelacja jest przypadkowa. Por. G. A. Ferguson, Y. Takane, Analiza statystyczna $w$ psychologii $i$ pedagogice, Warszawa 1997.

${ }_{14}$ Na podstawie: A. Sułek, Psychospołeczne uwarunkowania patriotyzmu..., s. 146-165 oraz: A. Sułek, Psychologiczne uwarunkowania postaw wobec ojczyzny i narodu. Implikacje z badań empirycznych, w: Aspekt wychowawczy umiłowania Ojczyzny i Narodu w myśli Papieża Jana Pawła II. Materiały xVII Ogólnopolskiego Forum Szkół Katolickich. Jasna Góra, 30 listopada 2 grudnia 2006, red. D. Domańska, Warszawa 2007, s. 80-89. 


\begin{tabular}{|c|c|c|c|c|c|}
\hline \multicolumn{3}{|c|}{ MĘŻCZYŹNI } & \multicolumn{3}{|c|}{ КОВIETY } \\
\hline Wygodne życie & $-0,416$ & .000 & Wygodne życie & $-0,294$ & .000 \\
\hline Przyjemność życia & $-0,389$ & .000 & $\begin{array}{l}\text { Przyjemność } \\
\text { życia }\end{array}$ & $-0,292$ & .000 \\
\hline Życie pełne wrażeń & $-0,381$ & .000 & Zbawienie & 0,289 & .000 \\
\hline Indywidualizm & $-0,378$ & .000 & $\begin{array}{l}\text { Potrz. } \\
\text { podporządk. się } \\
\text { (Def-ideal) }\end{array}$ & 0,285 & .000 \\
\hline $\begin{array}{l}\text { Patriot. oddział. } \\
\text { szkoły }\end{array}$ & 0,359 & .000 & Indywidualizm & $-0,280$ & .000 \\
\hline Aprobata społeczna & 0,359 & .000 & Wyrozumiałość & 0,276 & .000 \\
\hline Zbawienie & 0,340 & .000 & Uczciwość & 0,260 & .001 \\
\hline $\begin{array}{l}\text { Patriot. oddział. } \\
\text { rówieśników }\end{array}$ & 0,329 & .000 & $\begin{array}{l}\text { Potrz. ekshibi- } \\
\text { cjon. (Exh-ideal) }\end{array}$ & $-0,258$ & .000 \\
\hline Samodzielność & $-0,325$ & .000 & Mądrość & 0,256 & .001 \\
\hline Pokój na świecie & 0,296 & .000 & $\begin{array}{l}\text { Potrz. porządku } \\
\text { (Ord-ideal) }\end{array}$ & 0,255 & .000 \\
\hline $\begin{array}{l}\text { Potrz. podporządk. } \\
\text { się (Def-real) }\end{array}$ & 0,294 & .000 & Posłuszeństwo & 0,247 & .001 \\
\hline $\begin{array}{l}\text { Potrz. autonomii } \\
\text { (Aut-real) }\end{array}$ & $-0,289$ & .000 & Uczynność & 0,246 & .001 \\
\hline Uczynność & 0,271 & .001 & $\begin{array}{l}\text { Potrz. wytrwa- } \\
\text { łośći (End-ideal) }\end{array}$ & 0,227 & .001 \\
\hline Kolektywizm & 0,257 & .001 & $\begin{array}{l}\text { Życie pełne } \\
\text { wrażeń }\end{array}$ & $-0,207$ & .006 \\
\hline $\begin{array}{l}\text { Potrz. porządku } \\
\text { (Ord-real) }\end{array}$ & 0,248 & .002 & $\begin{array}{l}\text { P. agresji } \\
\text { (Agg-ideal) }\end{array}$ & $-0,197$ & .005 \\
\hline $\begin{array}{l}\text { Potrz. ekshibicjon. } \\
\text { (Exh-real) }\end{array}$ & $-0,236$ & .002 & $\begin{array}{l}\text { Patriot. oddział. } \\
\text { rówieśników }\end{array}$ & 0,196 & .005 \\
\hline $\begin{array}{l}\text { Potrz. wytrwałości } \\
\text { (End-real) }\end{array}$ & 0,229 & .003 & Ambicja & $-0,182$ & .017 \\
\hline Pomysłowość & $-0,224$ & .008 & $\begin{array}{l}\text { Logiczność } \\
\text { myślenia }\end{array}$ & $-0,179$ & .018 \\
\hline Posłuszeństwo & 0,208 & .013 & $\begin{array}{l}\text { Potrz. } \\
\text { rozumienia } \\
\text { (Int-ideal) }\end{array}$ & 0,177 & .010 \\
\hline Równość ludzi & 0,192 & .023 & $\begin{array}{l}\text { Potrz. opie- } \\
\text { kowania się } \\
\text { (Nur-ideal) }\end{array}$ & 0,176 & .010 \\
\hline $\begin{array}{l}\text { Potrz. opiekowania } \\
\text { się (Nur-real) }\end{array}$ & 0,186 & .013 & Piękno świata & 0,174 & .022 \\
\hline $\begin{array}{l}\text { Potrz. poniżania się } \\
\text { (Aba-real) }\end{array}$ & 0,170 & .022 & Pomysłowość & $-0,163$ & .033 \\
\hline
\end{tabular}




\begin{tabular}{lcclcc}
\hline \multicolumn{3}{c}{ MĘżCZYŹNI } & & \multicolumn{3}{c}{ KOBIETY } & \\
\hline $\begin{array}{l}\text { Potrz. osiągnięć } \\
\text { (Ach-real) }\end{array}$ & 0,169 & .023 & Czystość & $-0,155$ & .042 \\
\hline Odpowiedzialność & 0,165 & .050 & Kolektywizm & 0,152 & .023 \\
\hline $\begin{array}{l}\text { Potrz. agresji } \\
\text { (Agg-real) }\end{array}$ & $-0,163$ & .027 & $\begin{array}{l}\text { Potrz. pod- } \\
\text { porządk. się } \\
\text { (Def-real) }\end{array}$ & 0,148 & .026 \\
\hline $\begin{array}{l}\text { Potrz. rozumienia } \\
\text { (Int-real) }\end{array}$ & 0,158 & .030 & $\begin{array}{l}\text { Potrz. autonomii } \\
\text { (Aut-real) }\end{array}$ & $-0,134$ & .040 \\
\hline
\end{tabular}

Badania zostały przeprowadzone zasadniczo wśród osób dorosłych, ale odzwierciedlają one proces kształtowania się u nich patriotyzmu od dzieciństwa, zatem wiedza o tym, jak kształtowały się te postawy w ich dzieciństwie jest przydatana do opracowywania projektów kształtowania postaw patriotycznych u obecnego najmłodszego pokolenia. Wyniki wskazują na uwarunkowania patriotyzmu zarówno takie, które są wspólne mężczyznom i kobietom, jak i takie, które są specyficzne dla mężczyzn i kobiet.

\section{Uwarunkowania patriotyzmu wspólne mężczyznom i kobietom}

Analiza porównawcza wyników mężczyzn i kobiet pozwala zauważyć następujące podobieństwa w aspekcie uwarunkowań patriotyzmu:

1. W obydwóch grupach wyraźny jest związek patriotyzmu $\mathrm{z}$ oddziaływaniami środowiskowo-społecznymi i religijnością, przy czym wydaje się, że dla kobiet większe znaczenie ma religijność, a dla mężczyzn większe znaczenie mają oddziaływania środowiskowo-społeczne. Postawa religijna implikuje powinność etyczną również wobec narodu i ojczyzny, a tym samym stanowi mocne oparcie dla kształtowania się patriotyzmu. Wysokie wyniki korelacji patriotyzmu z religijnością uzasadniają konieczność uwzględniania treści religijnych w wychowaniu patriotycznym, a nawet pozwalają postawić hipotezę, że pominięcie wartości religijnych $\mathrm{w}$ procesie wychowania patriotycznego może je narazić na niepowodzenie. Jako mocneo źródła patriotyzmu jawią się: zaszczepianie uczuć patriotycznych oraz wychowanie religijno-patriotyczne realizowane przez dom i Kościół oraz szkołę i rówieśników, a także inspirowana uczuciami konkretna aktywność patriotyczna.

Osoby o wysokich wynikach w skali patriotyzmu często wymieniają obecne w swoich wspomnieniach takie sytuacje z domu rodzinnego, jak: wspólne czytanie polskich książek, organizowanie obchodów rocznic i świąt narodowych, 
modlitwy za ojczyznę, pielęgnowanie tradycji ojczystych, rozmowy o sprawach Polski, śpiewanie pieśni patriotycznych i biesiadnych, traktowanie udziału w wolnych wyborach jako ważnego obowiązku obywatelskiego wobec ojczyzny, obecność w domu reprodukcji, obrazów, dzieł sztuki o tematyce narodowej, zainteresowanie bieżącymi wydarzeniami w kraju. Wspominają też szkołę, w której się uczyły, jako miejsce, gdzie mówiono o patriotyzmie, słyszano pochwałę bohaterstwa historycznych postaci Polaków, dbano o organizowanie akademii i uroczystości patriotycznych, organizowano konkursy wiedzy o Polsce, o regionie, okolicy, o własnej miejscowości, gdzie poprzez ciekawie prowadzone lekcje języka ojczystego i historii nauczyciele uwrażliwiali na piękno języka polskiego oraz uczyli miłości do kultury ojczystej, gdzie uczniowie spotykali nauczycieli - pasjonatów piękna polskiej kultury i polskiego krajobrazu, gdzie wystrój pomieszczeń szkolnych budził pozytywne emocje i tworzył klimat sprzyjający zainteresowaniu ojczyzną.

Postawa patriotyczna wynika również z patriotycznych oddziaływań Kościoła, wśród których osoby o wysokim poziomie patriotyzmu wymieniają: lekcje religii poruszające problematykę patriotyzmu, narodu, ojczyzny, kazania patriotyczne, organizowane w kościele obchody rocznic patriotycznych i nabożeństwa za ojczyznę, wystawy o tematyce historycznej i patriotycznej, wycieczki do ważnych i ciekawych miejsc historycznych w Polsce, konkursy poświęcone wiedzy o ojczyźnie, troska o obecność w kościele obrazów, rzeźb, gablot o tematyce patriotycznej i historycznej, podkreślanie w pracy wychowawczej Kościoła, że uczymy się i pracujemy nie tylko dla siebie, ale także dla dobra ojczyzny, podkreślanie obowiązków wobec ojczyzny.

Ważną rolę w kształtowaniu postaw patriotycznych odgrywa również patriotyczna aktywność własna. Osoby, które uzyskały wysoki wynik w skali patriotyzmu, wskazywały na takie jej formy, jak: dobrowolne włączanie się w organizowanie obchodów patriotycznych, warty honorowe, troska o groby polskich żołnierzy, ofiar wojny lub grób nieznanego żołnierza, czynny udział w wieczornicach patriotycznych i akademiach (śpiewanie pieśni, recytowanie wierszy), dekorowanie domu w dniach świąt narodowych i rocznic patriotycznych, czytanie z własnej inicjatywy publikacji oraz oglądanie programów ubogacających zdobytą w szkole wiedzę o Polsce i ważnych wydarzeniach w jej historii, wycieczki do ważnych historycznie miejsc w Polsce oraz chętne zwiedzanie izb pamięci narodowej i muzeów.

Wpływ grup odniesienia i rówieśników na kształtowanie postaw patriotycznych zaznaczał się poprzez dostrzegane u rówieśników duże zainteresowanie 
sprawami ojczyzny oraz obchodami świąt narodowych, ich rozmowy o aktualnych problemach Polski, zwiedzanie przez nich miejsc historycznych w Polsce, ich przynależność do harcerstwa i innych związków, klubów, organizacji, dla których sprawy narodu i ojczyzny były ważne, ich udział w nabożeństwach za ojczyznę, ich deklaracje gotowości do pracy na rzecz ojczyzny za darmo przez jakiś czas i gotowości nawet oddania życia za ojczyznę, potwierdzanie, że w ich domu pielęgnuje się tradycje i zwyczaje ojczyste.

Wszystkie wymienione wyżej formy oddziaływań społecznych stanowią konkretne propozycje zastosowań w wychowaniu patriotycznym dzieci i młodzieży.

2. System wartości okazał się ważnym źródłem postaw patriotycznych dla przedstawicieli obydwóch płci. Patriotyzm będzie tym mocniejszy, im niższa będzie preferencja wartości: wygodne życie, przyjemność życia, życie pełne wrażeń, pomysłowość oraz im wyższa będzie preferencja wartości: zbawienie, uczynność, posłuszeństwo. Patriotyzm powiązany jest z niską preferencją wartości intrapersonalnych, spraw osobistych, jak dostatnie, wygodne życie, przyjemność życia, zakładająca życie według własnych upodobań oraz pobudzające, aktywne życie pełne wrażeń, a także z niską preferencją osobistych walorów intelektualnych. Patriotyzm wiąże się z preferencją troski o życie wieczne oraz $\mathrm{z}$ wyborem realizacji dobra dla innych i $\mathrm{z}$ wychodzeniem poza wąsko pojmowane dobro indywidualne czy interes osobisty. Wnioskiem z tej części badań jest wyraźny postulat wychowywania dzieci z akcentem na poszanowanie dobra wspólnego - począwszy od wspólnej z rodzeństwem książki czy zabawki (szanuję ją, bo to jest nasza książka), zieleni w parku czy trawy na skwerze (których nie należy niszczyć i zaśmiecać, bo wszystkim służą i wszyscy się nią cieszymy) itd. Następnym postulatem w świetle powyższych wyników jest wysiłek w kierunku wypracowywania u dzieci i młodzieży umiejętności pracy wspólnej oraz widzenia siebie nie jako wyizolowanej jednostki, ale jako członka grupy. Jest to przechodzenie od „ja” do „my”, np. od „mówiłem wierszyk na akademii” do uchwycenia, że „nasza klasa wzięła udział w akademii”, od „wygrałem mecz” do „nasza drużyna wygrała”. Można więc powiedzieć, że szansę zostania patriotą ma dziecko, które wypracuje pojęcie dobra wspólnego oraz będzie miało poczucie przynależności do grupy. Wypracowane pojęcie dobra wspólnego oraz poczucie przynależności do grupy pozwala dziecku rozumieć ojczyznę jako dobro wspólne oraz postrzegać naród jako dużą grupę, do której ono też należy.

3. W obydwóch grupach wysokim wynikom patriotyzmu odpowiadają wysokie wyniki w skali kolektywizmu i niskie wyniki w skali indywidualizmu. 
Można więc powiedzieć, że patriotyzm będzie wzrastał tym bardziej, im bardziej uda się u młodych ludzi pokonać tendencje do szukania niezależności i działań indywidualnych czy odseparowywania się od grupy oraz im bardziej uda się wypracować dążenie do poszukiwania oparcia w grupie i zdolność do przenoszenia wartości i celów grupy ponad własne.

4. Wyodrębnienie szeregu potrzeb, które korelują z patriotyzmem $\mathrm{w}$ obydwóch grupach, pozwala zakładać, że łatwiej wychowywać do patriotyzmu dzieci, które potrafią wypracować w sobie sumienność, skromność, cierpliwość, bezkonfliktowość, zdolność do ulegania innym, unikanie ryzyka oraz chcą być stałe i konsekwentne w dążeniu do celu, zdyscyplinowane, zdolne do wysiłku, sumienne, obowiązkowe, solidne, bezkonfliktowe, cierpliwe, zdolne do współczucia i współpracy, uległe wobec przełożonych, niechętne do rywalizacji i agresji, niechętne do przyciągania uwagi innych oraz do manipulowania innymi.

\section{Uwarunkowania patriotyzmu charakterystyczne dla mężczyzn}

Analiza związków korelacyjnych pozwala też zauważyć zależności, które pojawiają się w grupie mężczyzn, a których nie stwierdza się w grupie kobiet:

1. Wartościami, które silnie pozytywnie korelują z patriotyzmem w grupie mężczyzn, a nie korelują z patriotyzmem w grupie kobiet są bezpieczeństwo narodowe, pokój na świecie, równość ludzi i odpowiedzialność. Są wartości zewnętrzne, odnoszące się do ogółu ludzkości lub dużej grupy, którą jest naród. Stąd zasadne wydaje się w wychowaniu patriotycznym chłopców zwracać uwagę na aspekty obronne, sukcesy oręża polskiego, militaria, prezentację sylwetek bohaterów narodowych oraz akcentowanie korzyści wynikających z pokoju między narodami. Stwierdzony w grupie mężczyzn ujemny związek patriotyzmu z samodzielnością (przy braku tego związku w grupie kobiet) podpowiada, że im mniej będzie w wychowaniu chłopców elementów konkurencji, a więcej elementów współpracy między uczniami, tym łatwiej będzie formować postawy patriotyczne.

2. Patriotyzm w grupie mężczyzn wysoko koreluje z potrzebą aprobaty społecznej, a nie stwierdza się takiego związku w grupie kobiet. Według powszechnego przekonania obrona ojczyzny i służba ojczyźnie jest zadaniem dla mężczyzn, spełnienie tego zadania jest nagradzane społecznie. Natomiast powszechnie nie oczekuje się takich postaw od kobiet. Dlatego w wychowaniu patriotycznym chłopcy powinni spotkać się z pochwałą zarówno poświęcenia 
dla ojczyzny i bohaterstwa w sytuacji zagrożenia, jak również z uznaniem dla służby ojczyźnie i narodowi oraz dla odpowiedzialnej pracy dla narodu i ojczyzny w warunkach pokoju.

3. Korelacje między skalami potrzeb a patriotyzmem, które występują w grupie mężczyzn, a których nie stwierdza się w grupie kobiet, pozwalają prognozować, że wychowaniu patriotycznemu chłopców będzie sprzyjać pochwała i wypracowywanie następujących cech: sumienność, cierpliwość, skromność, umiejętność kontrolowania impulsów i konsekwentnego dążenia do celu, pracowitość, obowiązkowość, zdolność do współczucia, bezkonfliktowość, taktowność, wyrozumiałość i pojednawczość oraz chęć nawiązywania i utrzymywania międzyludzkich przyjaźni.

\section{Uwarunkowania patriotyzmu charakterystyczne dla kobiet}

Pojawiły się też takie korelacje, które zachodzą w grupie kobiet, lecz nie zachodzą w grupie mężczyzn:

Wartościami, które dodatnio korelują z patriotyzmem w grupie kobiet, a nie ma takiego związku w grupie mężczyzn są: wyrozumiałość, uczciwość, mądrość, piękno świata. Oznacza to, że u kobiet patriotyzm o wiele bardziej niż u mężczyzn wiąże się z docenianiem relacji międzyludzkich oraz zachwytem nad pięknem natury i sztuki. Stąd w wychowaniu patriotycznym dziewczęta powinny spotkać się ze zwróceniem uwagi na piękno polskiego krajobrazu, roślinności, dzieł kultury i sztuki (architektury, malarstwa, rzeźby, literatury, muzyki). Stwierdzony też w grupie kobiet ujemny związek patriotyzmu z takimi wartościami, jak: ambicja, czystość i logiczność myślenia (przy braku takowego związku w grupie mężczyzn) wskazuje na to, iż w kształtowaniu patriotyzmu u dziewcząt bardziej niż w kształtowaniu patriotyzmu u chłopców przeszkadzać będzie zbyt mocne dążenie do samorealizacji, nadmierne umiłowanie porządku wokół siebie oraz przecenianie własnych możliwości i kompetencji. W świetle tych wyników należałoby dziewczętom raczej ostrożnie forsować model tzw. „silnej kobiety”, osiągającej sukcesy i zdeterminowanej w dążeniu do celu, gdyż z pewnością prezentowanie takiego modelu będzie sprzyjać robieniu kariery, ale może osłabiać motywację do rozwijania postaw społecznych, w tym również patriotyzmu. 


\section{W kierunku integracji oddziaływań wychowawczych szkoły i rodziny}

Badania dowodzą, że decydującą rolę w procesie kształtowania postaw patriotycznych odgrywają czynniki związane z rolą domu rodzinnego, Kościoła, szkoły, aktywności własnej oraz rówieśników. Jest to zgodne z psychologiczną wiedzą, według której na kształtowanie się postaw w okresie dzieciństwa największy wpływ mają rodzice. Dzieci, nawet już jako dorosłe osoby, mają poglądy w kwestii religii, polityki czy wychowania bliskie poglądom rodziców ${ }^{15}$. Stanisław Mika ${ }^{16}$ wyjaśnia tę wielką skuteczność wpływu rodziców tym, że dbają oni o zaspokajanie wszystkich podstawowych potrzeb dziecka, zarówno biologicznych, jak i emocjonalnych i poznawczych. Zaspokajanie potrzeb spełnia tu rolę licznych wzmocnień, które są stosowane przez rodziców w celu nauczenia dziecka pożądanych czynności, zachowań i postaw. Zaspokajanie przez rodziców potrzeb dziecka sprawia, że dziecko ma do rodziców pozytywny stosunek, co z kolei sprzyja traktowaniu rodzica jako modela, którego zachowania i postawy dziecko przejmuje. Podobną do rodziców rolę spełnia nauczyciel, zwłaszcza w początkowym etapie edukacji szkolnej. Nauczyciel umożliwia dzieciom zaspokajanie potrzeb poznawczych i emocjonalnych, zazwyczaj zyskuje w oczach dziecka duże znaczenie, co sprawia, że podobnie jak rodzic, pełni on rolę modela, którego postawy i zachowania uczniowie chętnie naśladują; tym samym nauczycielowi jest łatwiej kształtować u dzieci pożądane postawy społeczne. Z biegiem czasu, zwłaszcza w okresie dorastania, rolę modela coraz częściej spełniają również koledzy - rówieśnicy i starsi. Wtedy też zmienia się nieco wpływ nauczycieli na postawy młodzieży; szczególnie ważny jest aspekt poznawczy postaw. Duże znaczenie dla trwałości i kształtu postaw ma aktywność własna jednostki: im większa osobista aktywność i więcej doświadczeń związanych z przedmiotem postawy, tym większa intensywność postawy i mniejsza jej podatność na zmiany ${ }^{17}$.

Wymienione powyżej prawidłowości pozwalają sformułować główne założenia współpracy rodziny i szkoły w obszarze kształtowania postaw patriotycznych u dzieci i młodzieży. Jest to potrzeba zaspokajania potrzeb poznawczych i emocjonalnych dzieci i młodzieży, właściwy przykład postaw nauczycieli

${ }_{15}$ B. Wojciszke, Postawy i ich zmiana, w: Psychologia. Podręcznik akademicki, t. 3: Jednostka w społeczeństwie i elementy psychologii stosowanej, red. J. Strelau, Gdańsk 200o, s. 84.

${ }^{16}$ S. Mika, Psychologia społeczna dla nauczycieli, Warszawa 1998, s. 133-134.

${ }^{17}$ B. Wojciszke, Postawy $i$ ich zmiana, s. 84 . 
i rodziców oraz wdrażanie dzieci i młodzieży do aktywności własnej, zwłaszcza w działaniach zespołowych z rówieśnikami. Aby to osiągnąć, w relacji szkołarodzice nie wystarczy nie szkodzić czy nie przeszkadzać sobie wzajemnie, ale odpowiadać pozytywnie na propozycje drugiej strony, a szczególnie kreować i realizować pomysły. Taka współpraca może zaowocować takimi ważnymi dla kształtowania postaw patriotycznych działaniami i pomysłami, jak: piknik rodzinny, wiejski, gminny, wieczornica, ognisko z pieśnią patriotyczną i biesiadną, konkursy, quizy (literackie, plastyczne, muzyczne, fotograficzne) o różnej tematyce (moja mała ojczyzna, patron szkoły, ciekawe miejsca, ciekawe osoby, historia miejscowości, regionu, kraju), prezentacje tematyczne, dzień flagi - dekorowanie domów i obiektów, szycie flag, turystyka krajowa, lokalna, regionalna.

Powyższa analiza nie wyczerpuje tematyki czynników ważnych w wychowaniu patriotycznym dzieci i młodzieży, ale daje możliwość praktycznego wykorzystania wyników badań w planowaniu i realizowaniu programów wychowania patriotycznego młodych pokoleń przy zaangażowaniu zarówno szkoły, jak i rodziców, a przede wszystkim dzieci i młodzieży.

\section{Bibliografia}

Adamska K., Mapa rzeczywistości społecznej indywidualisty i kolektywisty - badania empiryczne, „Przegląd Psychologiczny” 3-4 (1997), s. 443-464.

Blok Z., Status teoretyczny kategorii: nacjonalizm, patriotyzm, kosmopolityzm i internacjonalizm, w: Człowiek i społeczeństwo, t. 11, Poznań 1994, s. 147-154. Brzozowski P., Polska wersja Testu Wartości Rokeacha i jej teoretyczne podstawy, „Przegląd Psychologiczny” 2 (1986), s. 527-540.

Drwal R. Ł., Wilczyńska J. T., Opracowanie Kwestionariusza Aprobaty Społecznej, „Przegląd Psychologiczny” 3 (1980), s. 569-583.

Ferguson G. A., Takane Y., Analiza statystyczna w psychologii i pedagogice, Warszawa 1997. Gough H. G., Heilbrun A. B., The Adjective Check List Manual, Paolo Alto 1965. Gough H. G., Heilbrun A. B., The Adjective Check List Manual, Paolo Alto 1983. Mądrzycki T., Psychologiczne prawidłowości kształtowania siępostaw, Warszawa 1977. Mika S., Psychologia społeczna dla nauczycieli, Warszawa 1998.

Prężyna W., Intensywność postawy religijnej a osobowość, Lublin 1973.

Prężyna W., Kryzys religijny a cechy osobowości, „Roczniki Filozoficzne” 1971 z. 4, S. $25-135$.

Prężyna W., Skala Postaw Religijnych, „Roczniki Filozoficzne” 1968 z. 4, s. 75-89. 
Rokeach M., The Nature of Human Values, New York 1973.

Sułek A., Psychologiczne uwarunkowania postaw wobec ojczyzny i narodu. Implikacje $z$ badań empirycznych, w: Aspekt wychowawczy umiłowania Ojczyzny i Narodu w myśli Papieża Jana Pawła II. Materiały XVII Ogólnopolskiego Forum Szkót Katolickich. Jasna Góra, 30 listopada - 2 grudnia 2006, red. D. Domańska, Warszawa 2007, s. 80-89.

Sułek A., Psychospołeczne uwarunkowania patriotyzmu i nacjonalizmu, Kraków 2012.

Śliwak J., Osobowość altruistyczna. Osobowościowe korelaty altruizmu, Lublin 2001. Wilczyńska J., Drwal R. Ł., Opracowanie Kwestionariusza Aprobaty Społecznej (кAS) J. Wilczyńskiej i R.Ł. Drwala, w: R. Ł. Drwal, Adaptacja kwestionariuszy osobowości. Wybrane zagadnienia i techniki, pod redakcją P. Brzozowskiego przy współpracy P. Olesia, Warszawa 1995, s. 57-66.

Wojciszke B., Postawy i ich zmiana, w: Psychologia. Podręcznik akademicki, t. 3: Jednostka w społeczeństwie i elementy psychologii stosowanej, red. J. Strelau, Gdańsk 2000, s. 79-106.

\section{Streszczenie}

Niniejszy artykuł podjął próbę odpowiedzi na pytanie, jakie cechy psychiczne oraz jakie czynniki społeczne stanowią źródła patriotyzmu. Najpierw został zdefiniowany patriotyzm jako postawa człowieka, który ma pozytywne i zaangażowane nastawienie do własnego narodu, ale ma również nastawienie pozytywne do innych narodów. Badania empiryczne wskazały wiele źródeł patriotyzmu, z których najważniejsze to oddziaływania środowiskowo-społeczne rodziny, szkoły, wspólnoty religijnej, grup rówieśniczych i aktywność własna. Doniosłą rolę odgrywa również religijność człowieka oraz preferowane wartości, szczególnie te, które odnoszą się do dobra wspólnego. Wnioski z tych analiz podkreślają konieczność uwzględniania w wychowaniu patriotycznym dzieci poczucia wspólnoty z grupą oraz poczucia dobra wspólnego, które cenią i o które się troszczą. Nie można też pominąć treści religijnych, bowiem religijność jest mocnym oparciem dla patriotyzmu, z niej wypływa powinność moralna wobec ojczyzny i narodu. Różnice w uwarunkowaniach patriotyzmu u mężczyzn i kobiet pozwalają formułować potrzebę zwracania u chłopców uwagi na współpracę międzyosobową, pochwałę bohaterstwa i odpowiedzialnej pracy dla ojczyzny, natomiast $\mathrm{w}$ wychowaniu patriotycznym dziewcząt warto akcentować piękno polskiego krajobrazu, przyrody oraz dzieł kultury i sztuki. 
We wszystkich tych poczynaniach konieczna jest współpraca rodziców i nauczycieli, gdyż stanowią oni ważne dla dzieci autorytety, od których uczą się postaw społecznych, w tym również postawy patriotycznej.

\section{Słowa kluczowe}

patriotyzm, postawy społeczne, wychowanie, rodzina, szkoła, religijność, wartości

\section{Summary}

\section{Cooperation of Family and School in Patriotic Education as an Expression of Concern for the Proper Development of the Child's Social Attitudes. Adoption of the Conclusions from the Study of Patriotic Education}

This article attempts to answer the question: what mental features and what social factors are the sources of patriotism? Patriotism was defined as the attitude of a human who has a positive and committed attitude towards his own nation, but also has an encouraging attitude regarding other nations. Empirical studies have indicated a number of sources of patriotism, the most important of which are environmental and social impacts of the family, school, religious community, peer groups and own self-activity. Human religiosity and favored values also play a significant role, especially those that relate to the common good. The conclusions from these analyzes emphasize the need for taking into account the children's sense of community with the group and the sense of the common good that they value and care for in patriotic education. It is of vital importance that religious content is not omitted or ignored, for religiosity is a strong support for patriotism, from which moral obligation flows towards the motherland and the nation. Differences in the motivation of patriotism in men and women allow us to formulate the need of drawing attention to interpersonal cooperation, praising of heroism and responsible work for the homeland. However, in the patriotic education of girls, it is worth emphasizing the beauty of the Polish landscape, nature and works of culture and art. All these endeavors require cooperation between parents and teachers, because they are important authorities for children and from whom children learn social attitudes, including the approach of being patriotic towards their nation and people.

\section{Keywords}

patriotism, social attitudes, education, family, school, religiosity, values 